\title{
Pengaruh Kinerja Pelayanan Terhadap Loyalitas Pelanggan
}

\author{
Devi Elvita $^{1 *}$ dan Tintin Suhaeni ${ }^{2}$ \\ ${ }^{1}$ Jurusan Administrasi Niaga, Politeknik Negeri Bandung, Indonesia \\ 2 Jurusan Administrasi Niaga, Politeknik Negeri Bandung, Indonesia
}

\begin{abstract}
:
This study aims to determine the performance of services and customer loyalty mail and parcel as well as how much the influence of service performance to customer loyalty of mail and parcel in PT Pos Indonesia Bandung. Quota sampling technique was used to collect data through questionnaires to 115 people who use the services of courier mail and parcel post with Likert scale. The analysis method used is the multiple regression. The results showed that the performance of services in PT Pos Indonesia are in the category of good/high in terms of interaction quality, physical environment quality, and outcome quality. While customer loyalty mail and parcel that are in the category of average in terms of repeat purchase, purchases across product and service line, refers others and demonstrates immunity to the pull of the competition. The conclusion is the performance of services significantly affect customer loyalty mail and parcel in PT Pos Indonesia Bandung amounted to $54.7 \%$.
\end{abstract}

Keywords: customer loyalty, influence, service performance

\section{LATAR BELAKANG}

Kemajuan suatu perusahaan dapat dilihat dari peningkatan kegiatan usaha yang dilakukan. Apabila suatu perusahaan memiliki usaha yang lancar dan maju, maka perusahaan mampu bersaing dengan perusahaan lain dalam dunia usaha. Hal ini terlihat dari semakin maraknya bidang usaha baik barang maupun jasa. Perkembangan bisnis jasa di Indonesia berkembang sangat pesat. Salah satunya bisnis jasa pada sektor jasa kurir, banyak sekali pesaing dalam bidang jasa kurir.

Salah satu strategi yang dapat menunjang keberhasilan usaha tersebut adalah berusaha menawarkan kualitas pelayanan yang tinggi yang ditunjukkan dengan kinerja pelayanan. Perusahaan harus dapat mengelola kinerja pelayanan dengan

\footnotetext{
*Email korespondensi:

Devi Elvita

devi.elvita22@gmail.com
}

tepat supaya memenuhi kebutuhan konsumen agar konsumen merasa puas serta akan terciptanya perasaan loyal pada konsumen atau loyalitas konsumen. Pelanggan yang loyal akan memberikan keuntungan kepada bisnis jasa. Hal ini dapat membantu perusahaan dalam menguasai pangsa pasar dan unggul dari para pesaing.

SERVPERF (Service Performance) atau kinerja pelayanan yang dikembangkan oleh Cronin dan Taylor (dalam Purwanto, 2015:89) menyatakan bahwa "ukuran kualitas jasa atau pelayanan adalah kinerja dari jasa atau pelayanan yang diterima oleh konsumen itu sendiri dan konsumen hanya akan dapat menilai kualitas dari pelayanan yang benar-benar mereka rasakan". Hal ini diperkuat dengan pernyataan Alford dan Sherrell (dalam Andri, 2011:59), bahwa "kualitas pelayanan atau service performance akan menjadi prediktor yang baik bagi kualitas jasa atau pelayanan". Apabila service performance yang diberikan 
perusahaan meningkat, maka kepuasan pelanggan juga akan meningkat sehingga akan berdampak pada meningkatnya loyalitas pelanggan.

Menurut Lucas (2015:378) bahwa "customer loyalty describe the tendency of customers to return to a product or organization regularly because of the service and satisfaction they receive" yaitu loyalitas pelanggan menggambarkan kecenderungan pelanggan untuk kembali ke produk atau organisasi secara teratur karena layanan dan kepuasan yang mereka terima. Loyalitas menggambarkan kesediaan pelanggan agar senantiasa menggunakan produk baik barang maupun jasa perusahaan dalam jangka panjang, menggunakan secara eksklusif, dan merekomendasikan kepada teman dan rekannya dimana tujuannya adalah untuk membangun hubungan dan menghadirkan pelanggan loyal yang akan terus menggunakan layanan perusahaan di masa mendatang (Lovelock dan Wirtz, 2011:76).

Kepuasan akan mendorong konsumen untuk mengulang perilaku pembelian atau konsumsi dan bila tidak puas akan menimbulkan kekecewaan yang justru menghentikan mengulang perilaku pembelian/konsumsi. Pembelian yang terus menerus dan berulang terhadap suatu produk dan merek yang sama akan menunjukkan loyalitas konsumen terhadap merek atau layanan (Sudaryono, 2014:49). Rendahnya kualitas akan menempatkan perusahaan pada kerugian kompetitif, berpotensi mengusir pelanggan yang tidak puas yang akan menurunkan rasa loyal pada pelanggan (Lovelock dan Wirtz, 2011:152). Loyalitas pelanggan tidak bisa tercipta begitu saja, tetapi harus dirancang oleh perusahaan yaitu salah satunya dengan menyokong dan meningkatkan kinerja (Morais, dalam Sangadji dan Sopiah, 2013:105).

PT Pos Indonesia (Persero) merupakan Badan Usaha Milik Negara (BUMN) yang bergerak di bidang jasa kurir, logistik, dan transaksi keuangan. PT Pos Indonesia (Persero) memiliki potensi besar di tiga bisnis intinya, yaitu bisnis surat dan paket, bisnis logistik, dan bisnis jasa keuangan. PT Pos Indonesia (Persero) masih tetap sebagai salah satu perusahaan jasa dengan jaringan distribusi yang terbesar di Indonesia. Penopang pendapatan PT Pos Indonesia (Persero) masih ada di bisnis surat pos dan jasa keuangan. Sumber pendapatan terpenting lainnya adalah jasa pembayaran, jasa pengiriman uang, dan pengiriman paket.

Berdasarkan data pada MarkPlus CSI (dalam PT Pos Indonesia, 2015), mayoritas pangsa pasar dikuasai oleh 3 pemain utama, yaitu Tiki, PT Pos Indonesia (Persero), dan Tiki JNE. PT Pos Indonesia berada pada posisi kedua dari pangsa pasar dengan presentase $34 \%$ untuk surat pos dan $27 \%$ untuk paket pos, sedangkan posisi pertama adalah Tiki dengan presentase $35 \%$ untuk surat dan 34\% untuk paket. Hal ini terlihat bahwa PT Pos Indonesia telah memasuki tingkat kompetisi yang sangat ketat dan memiliki banyak pesaing.

Berdasarkan data produksi surat dan paket di PT. Pos Indonesia (2015), produksi surat dan paket pos mengalami penurunan dari tahun 2013 s.d 2015. Pada tahun 2014, surat pos mengalami penurunan sebesar 78.775 ribu pucuk dari tahun sebelumnya, sedangkan paket pos mengalami penurunan sebesar 6.531 ribu pucuk dari tahun sebelumnya. Pada tahun 2015, surat pos mengalami penurunan sebesar 209.829 ribu pucuk dari tahun sebelumnya, sedangkan paket pos mengalami penurunan sebesar 20.382 ribu pucuk dari tahun sebelumnya. Penurunan produksi surat dan paket pos pada tahun 2015 sangat drastis dibandingkan dengan tahun sebelumnya.

Berdasarkan data pengaduan pelanggan kepada PT. Pos Indonesia Bandung, jumlah pengaduan pelanggan kepada PT Pos Indonesia Bandung dari tahun 2013 s.d 2015 mengalami peningkatan. Pada tahun 2014, pengaduan pelanggan meningkat sebesar 1.011 dari tahun sebelumnya dan pada tahun 2015, pengaduan pelanggan meningkat sebesar 1.919 dari tahun sebelumnya. Pengaduan 
pelanggan tertinggi terjadi pada tahun 2015 yaitu sebesar 5.608.

Masalah yang sering diadukan oleh konsumen yaitu tentang keterlambatan atau belum diterimanya kiriman, kehilangan, kiriman tidak utuh, salah serah, permintaan data/berita acara, salah update status, pengembalian/retur, salah salur, dan salah tempel resi. Jenis masalah yang sering kali diadukan oleh pelanggan atau masalah yang memiliki jumlah pengaduan terbanyak yaitu tentang keterlambatan/belum diterimanya kiriman pelanggan. Pada tahun 2015, jumlah pengaduan mengenai keterlambatan atau belum diterimanya kiriman pelanggan merupakan jumlah pengaduan yang tertinggi yaitu sebesar 3.622 dibandingkan dengan tahun sebelumnya, dimana pada tahun 2013 sebesar 1.506 dan tahun 2014 sebesar 2.070.

PT Pos Indonesia tidak mengabaikan pengaduan pelanggan karena pengaduan dan informasi yang diterima akan dijadikan masukan untuk ditindak lanjuti guna perbaikan kualitas dari kinerja pelayanan dan meningkatkan kepuasan pelanggan yang akan menimbulkan loyalitas pelanggan. Pelanggan dapat mengadu melalui customer service, website, contact center, facebook, dan twitter. PT Pos Indonesia akan memberikan solusi dan bertanggungjawab atas permasalahan-permasalahan tersebut.

Pelanggan dapat dikatakan loyal apabila pelanggan puas dengan kinerja pelayanan PT Pos Indonesia dengan mengedepankan kualitas dari kinerja pelayanan dan kecepatan serta ketepatan waktu. PT Pos Indonesia juga harus memenuhi komitmen dari segi tarif, kualitas, waktu tempuh kiriman, jaminan produk maupun layanan purna jual sesuai ketentuan perusahaan, peraturan dan perundangan yang berlaku.

Jika dilihat dari data-data tersebut, maka dapat diasumsikan bahwa konsumen tidak puas dengan kinerja pelayanan PT Pos Indonesia untuk surat dan paket pos yang mengakibatkan loyalitas konsumen berkurang, dimana kualitas pelayanan pada kinerja pelayanan mengalami penurunan.
Hal itu terlihat dari jumlah produksi surat dan paket pos yang menurun dari tahun 2013 s.d 2015 serta terlihat dari jumlah pengaduan pelanggan yang meningkat dari tahun 2013 s.d 2015.

\section{TINJAUAN PUSTAKA \\ Kinerja Pelayanan}

SERVPERF (service performance) atau kinerja pelayanan atau performancebased service quality yang dikembangkan oleh Cronin dan Taylor (dalam Purwanto, 2015:89) menyatakan bahwa "service performance merupakan ukuran kualitas jasa atau pelayanan adalah kinerja dari jasa atau pelayanan yang diterima oleh konsumen itu sendiri dan konsumen hanya akan dapat menilai kualitas dari pelayanan yang benarbenar mereka rasakan". Kinerja pelayanan juga disebut perceive performance atau persepsi kinerja. Menurut Tjiptono dan Chandra (2011:308), "perceive performance merupakan keyakinan pelanggan mengenai jasa yang dialami atau beliefs about experience service". Cronin dan Taylor mengembangkan model pengukuran kualitas pelayanan atau jasa hanya pada kinerja atau performance nya saja, dan tidak menggunakan harapan (Sultan dan Wong, 2010:128).

Menurut Brady dan Cronin (dalam Tjiptono dan Chandra, 2011:263), kualitas jasa memiliki tiga dimensi yaitu:

1. Kualitas interaksi (interaction quality), terdiri dari:
a. Sikap karyawan
b. Perilaku karyawan
c. Keahlian karyawan

2. Kualitas lingkungan fisik (physical environment quality), terdiri dari:

a. Ambient conditions mengacu pada aspek-aspek non-visual, seperti temperatur, musik, dan aroma.

b. Desain fasilitas meliputi layout atau arsitektur lingkungan dan bisa fungsional (praktikal) maupun estetis (menarik secara visual) 
c. Faktor sosial berupa jumlah dan tipe orang yang ada dalam setting jasa, beserta perilaku mereka.

3. Kualitas hasil (outcome quality), terdiri dari:

a. Waktu tunggu yang diukur bukanlah waktu tunggu yang absolut, namun persepsi pelanggan terhadap lamanya waktu menunggu penyampaian jasa.

b. Bukti fisik (tangible evidence) mencerminkan fasilitas fisik yang relevan dalam jasa bersangkutan.

Valensi (valence) mengacu pada atribut-atribut yang mempengaruhi keyakinan pelanggan bahwa hasil suatu jasa itu baik atau buru

\section{Loyalitas Pelanggan}

Menurut Lucas (2015:378)

menyatakan bahwa "customer loyalty describe the tendency of customers to return to a product or organization regularly because of the service and satisfaction they receive" yaitu loyalitas pelanggan menggambarkan kecenderungan pelanggan untuk kembali ke produk atau organisasi secara teratur karena layanan dan kepuasan yang mereka terima. Menurut Griffin (2005:16) bahwa "loyalitas pelanggan didasarkan pada wujud perilaku dari unitunit pengambilan keputusan untuk melakukan pembelian secara terus-menerus terhadap produk atau jasa suatu perusahaan yang dipilih". Loyalitas pelanggan merupakan perilaku yang mencakup preferensi, kesukaan, dan itikad di masa mendatang, dimana tujuan perusahaan berupaya membangun dan memelihara loyalitas pelanggan adalah untuk membangun hubungan dan menghadirkan pelanggan loyal yang akan terus menggunakan layanan perusahaan di masa mendatang (Lovelock dan Wirtz, 2011:316).

Menurut Griffin (2005:31) menyatakan bahwa pelanggan yang loyal memiliki karakteristik sebagai berikut:

1. Melakukan pembelian berulang secara teratur (makes regular repeat purchases), yaitu konsumen melakukan pembelian secara continue pada suatu produk atau jasa tertentu.

2. Membeli antarlini produk atau jasa (purchases across product and service lines), yaitu konsumen tidak hanya membeli satu jenis produk atau jasa, tetapi konsumen juga membeli produk atau jasa yang lain dari perusahaan yang sama.

3. Merekomendasikan kepada orang lain (refers others), yaitu dimana konsumen melakukan komunikasi dari mulut ke mulut (word of mouth) berkenaan dengan produk atau jasa tersebut.

4. Menunjukkan kekebalan terhadap daya tarik pesaing (demonstrates immunity to the pull of the competition), yaitu konsumen menolak untuk menggunakan produk atau jasa alternatif yang ditawarkan oleh pesaing.

Menurut Griffin (2005:22) terdapat empat jenis loyalitas muncul bila keterikatan rendah dan tinggi diklasifikasikan silang dengan pola pembelian ulang yang rendah dan tinggi. Hal itu dapat dilihat pada gambar 1

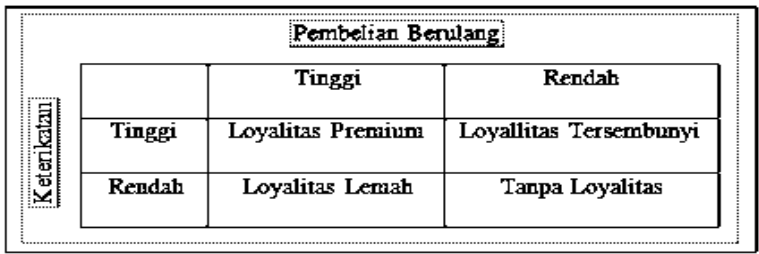

Gambar 1 Empat Jenis Loyalitas

\section{Kerangka Pemikiran}

Menurut Wijaya (2011:23), dengan memperhatikan kinerja pelayanan pada kualitas jasa maka akan memperkuat loyalitas pelanggan, yaitu pelayanan yang baik yang diberikan suatu perusahaan akan membuat pelanggan merasa nyaman dengan perusahaan sehingga timbul loyalitas pelanggan karena mereka merasakan kepuasan dengan pelayanan yang diberikan. Kualitas memberikan suatu dorongan kepada pelanggan untuk menjalin ikatan hubungan yang kuat dengan perusahaan (Sangadji dan Sopiah, 2013:116). 
Kinerja pelayanan diukur dengan menggunakan tiga dimensi kualitas pelayanan yang dikembangkan oleh Brady dan Cronin (dalam Tjiptono dan Chandra, 2011:263) yaitu kualitas interaksi (interaction quality), kualitas lingkungan fisik (physical environment quality), dan kualitas hasil (outcome quality). Selanjutnya pengukuran loyalitas pelanggan diukur dengan menggunakan empat dimensi loyalitas pelanggan yang dikembangkan oleh Griffin (2005:31) yaitu melakukan pembelian berulang secara teratur (repeat purchase), membeli antarlini produk atau jasa (purchases across product and service line), merekomendasikan kepada orang lain (refers others), dan menunjukkan kekebalan terhadap daya tarik pesaing (demonstrates immunity to the pull of the competition).

\section{Hipotesis}

Berdasarkan hasil penelitian terdahulu, penjelasan mengenai hubungan kualitas pelayanan dengan loyalitas pelanggan, serta berdasarkan dari penjelasan kerangka pemikiran dari penelitian ini, maka dapat dirumuskan bahwa hipotesis dalam penelitian ini adalah sebagai berikut:

$\mathrm{H}_{\mathrm{o}}$ : Kinerja pelayanan tidak berpengaruh secara signifikan terhadap loyalitas pelanggan surat dan paket di PT Pos Indonesia Bandung.

$\mathrm{H}_{\mathrm{a}}$ : Kinerja pelayanan berpengaruh secara signifikan terhadap loyalitas pelanggan surat dan paket di PT Pos Indonesia Bandung.

\section{METODE PENELITIAN}

Metode penelitian yang digunakan adalah metode penelitian kuantitatif. Hubungan variabel yang digunakan dalam metode penelitian kuantitatif adalah hubungan sebab-akibat (kausal), dimana pada penelitian ini terdapat variabel independen dan dependen yang selanjutnya akan dicari hubungan antara variable tersebut dan seberapa besar pengaruh variabel independen terhadap variabel dependen (Sugiyono, 2014:68).
Populasi dalam penelitian ini adalah seluruh pelanggan PT Pos Indonesia Bandung yang menggunakan jasa kurir surat dan paket pos, dan populasi tidak diketahui dikarenakan belum adanya sistem CRM. Teknik penarikan sampel yang digunakan dalam penelitian ini adalah non-probability sampling yang berdasarkan quota sampling. Penarikan sampel berdasarkan ciri-cri tertentu yaitu pelanggan surat dan paket di PT Pos Indonesia Bandung dengan jumlah kuota yang ditetapkan oleh peneliti yaitu sebanyak 115 responden. Data penelitian terdiri dari data primer yaitu kuesioner, serta data sekunder yaitu buku, jurnal, skripsi, dokumen perusahaan, dan study literature lainnya.

Kuesioner dalam penelitian ini menggunakan skala likert dengan bobot nilai 1-5. Uji validitas dan reliabilitas telah dilakukan dengan hasil bahwa semua pernyataan dinyatakan valid karena nilai corrected item-total correllations diatas 0,30 atau $\geq 0,30$ dan reliabel karena nilai cronbach's alpha > 0,6 atau lebih dari 0,6.

Analisis dilakukan dengan menggunakan uji asumsi klasik (uji normalitas, heterokedastisitas, dan linearitas), analisis deskriptif, analisis korelasi, analisis regresi linier sederhana, koefisien determinasi, dan uji hipotesis (Uji F dan Uji t).

\section{HASIL DAN PEMBAHASAN Analisis Deskriptif Kinerja Pelayanan}

Jika dilihat pada tabel 1, variabel kinerja pelayanan memiliki rata-rata (mean) sebesar 3,66 sehingga berada pada interval 3,40 - 4,19 yang artinya kinerja pelayanan di PT Pos Indonesia Bandung berada pada tingkat yang baik/tinggi. Hal ini mengindikasikan bahwa kinerja pelayanan di PT Pos Indonesia Bandung dinilai baik/tinggi dalam kualitas berdasarkan sikap dan perilaku karyawan kepada konsumen, keahlian karyawan dalam menguasai pekerjaannya, kondisi kantor pos yang terawat dan rapi, kecepatan karyawan dalam melayani konsumen, ketepatan waktu 
tunggu pengiriman dengan yang dijanjikan, fasilitas kantor pos yang lengkap serta peralatan yang modern, ketelitian dalam memberikan pelayanan dan keamanan dari pelayanan yang diberikan. Menurut Brady dan Cronin (dalam Tjiptono dan Chandra, 2011:263), kinerja pelayanan terdiri dari tiga dimensi yaitu kualitas interaksi (interaction quality), kualitas lingkungan fisik (physical environment quality), dan kualitas hasil (outcome quality).

Dimensi interaction quality tergolong kategori baik/tinggi dengan mean sebesar 3,84. Hal ini mengindikasikan bahwa kualitas interaksi dari para karyawan PT Pos Indonesia Bandung kepada pelanggan PT Pos Indonesia Bandung dinilai baik/tinggi berdasarkan sikap para karyawan yang ramah dan sopan kepada konsumen dalam memberikan layanan, perilaku karyawan yang cepat tanggap dalam melayani kebutuhan konsumen serta mendengarkan keluhan konsumen, keahlian karyawan dalam memenuhi kebutuhan pelanggan serta mampu menyelesaikan permasalahan yang dihadapi pelanggan dengan cepat terkait jasa yang digunakan oleh konsumen dan karyawan mampu berkomunikasi dengan baik. Berdasarkan hasil pengamatan dilapangan, yakni para karyawan di PT Pos Indonesia bersikap sopan dan ramah kepada pelanggan serta berperilaku baik seperti karyawan menyapa pelanggan yang baru masuk ke kantor pos dan menanyakan keperluan dari pelanggan dengan sopan dan ramah, dan tanggap kepada pelanggan dengan merespon pertanyaan atau keluhan pelanggan dengan cepat seperti pada saat pelanggan menanyakan loket untuk pengiriman surat dan paket, karyawan memberitahukan loket yang harus dituju, dan apabila ada keluhan dari pelanggan, karyawan merespon keluhan pelanggan dan memberikan solusi terkait permasalahan yang dialami oleh pelanggan seperti apabila ada kiriman pelanggan yang belum sampai, maka karyawan akan mengecek lokasi kiriman dan memberitahukan kepada pelanggan. Para karyawan PT Pos Indonesia Bandung menguasai bidang pekerjaannya masingmasing sesuai dengan kompetensinya, seperti untuk karyawan bagian paket pos mengetahui waktu pengiriman, harga kiriman, dan jenis barang yang akan dikirim seperti apabila ada barang berdasar kaca, maka akan disarankan untuk menambah bungkusannya agar tidak pecah. Hal tersebut sesuai dengan teori menurut Liao dan Chuang (dalam Purwanto, 2015:90), bahwa indikator untuk kinerja pelayanan diantaranya ramah dalam membantu pelanggan, kecepatan dalam memahami pelanggan, mengajukan pertanyaan yang baik dan mendengarkan untuk mencari tahu apa yang diinginkan pelanggan, mampu membantu pelanggan bila diperlukan, menunjukkan kebutuhan yang berkaitan dengan pelanggan, menyarankan kebutuhan pelanggan yang tidak terpikirkan olehnya, menjelaskan fitur dan manfaat produk jika pelanggan keberatan.

Dimensi physical environment quality tergolong kategori baik/tinggi dengan mean sebesar 3,53. Hal ini mengindikasikan bahwa kualitas lingkungan fisik di PT Pos Indonesia Bandung dinilai baik/tinggi berdasarkan kebersihan dan terawatnya kantor pos, pemilihan warna pada kantor pos membuat pelanggan merasa nyaman, desain ruangan kantor pos yang tersusun rapi serta memberikan kenyamanan kepada pelanggan, jumlah karyawan di loket memadai dan karyawan berpenampilan rapi. Berdasarkan hasil pengamatan dilapangan, yakni lingkungan kantor pos terlihat bersih karena selalu dibersihkan oleh karyawan kebersihan, kantor pos memiliki desain ruangan yang tersusun rapi dan luas seperti ada tempat parkir, ada ruang tunggu, ada ruang customer service, ada ruang untuk surat, ada ruang untuk paket, dan pelanggan tidak berdesak-desakan saat mengantri, pemilihan warna pada kantor pos membuat pelanggan merasa nyaman seperti tidak menyilaukan mata, jumlah karyawan yang berada di loket memadai yaitu loket dibagibagi berdasarkan jasa yang akan digunakan 
sehingga pelanggan akan langsung masuk ke loket yang bersangkutan, dan para karyawan di PT Pos Indonesia Bandung berpakaian rapi dan sering menggunakan pakaian seragam dan setema dengan kantor pos. Hal tersebut sesuai dengan teori menurut Laksmi, Gani, dan Budiantoro (2015:172) bahwa dalam undang-undang perkantoran, The Offices Act, terdapat peraturan yang mengatur lingkungan fisik, beberapa diantaranya yaitu kebersihan (selain kebersihan gedung, juga terkait dengan kebersihan perlengkapan dan perabotan kantor), luas ruangan sebaiknya diperuntukkan untuk sejumlah pekerja dengan standar bahwa satu pekerja memiliki luas ruangan sebesar $3,7 \mathrm{~m}^{2}$, warna memengaruhi jiwa seseorang dan digunakan untuk meredam cahaya. Menurut Baker dalam Bohl (2012:6) faktor desain fasilitas merupakan isyarat fisik yang pelanggan amati dan mempengaruhi tingkat kesenangan dalam pengalaman layanan termasuk tata letak dan kenyamanan, serta faktor-faktor sosial termasuk penampilan dan perilaku karyawan akan berdampak pada perilaku konsumen.

Dimensi outcome quality tergolong kategori baik/tinggi dengan mean sebesar 3,60. Hal ini mengindikasikan bahwa kualitas hasil yang dirasakan atau yang dialami oleh pelanggan surat dan paket di PT Pos Indonesia Bandung dinilai baik/tinggi berdasarkan kecepatan dalam pelayanan, waktu tunggu pengiriman surat dan paket sesuai dengan yang dijanjikan, fasilitas yang lengkap, peralatan yang modern, ketepatan waktu pengiriman surat dan paket, kesesuaian surat dan paket yang dikirim dengan yang diterima, keamanan kiriman, status pengiriman dan penerimaan surat dan paket yang selalu sesuai. Berdasarkan hasil pengamatan dilapangan, yakni kecepatan karyawan dalam melayani pelanggan seperti antrian tidak menumpuk, fasillitas di PT Pos Indonesia lengkap, salah satunya tersedianya fasilitas untuk jasa kurir surat dan paket seperti tersedianya tempat untuk pemasangan perangko di surat dan ada tempat khusus untuk paket, serta peralatan yang digunakan modern seperti tersedianya komputer. Jika dilihat dari jawaban responden terkait pengalaman responden pada waktu menggunakan jasa kurir surat dan paket yang sudah baik/tinggi yaitu surat dan paket yang dikirim sampai ditempat tujuan tepat waktu, surat dan paket yang diterima sesuai dengan yang dikirim dan tidak rusak, serta status pengiriman dan status penerimaan surat dan paket pos yang diterima selalu sesuai.

Namun, ada beberapa permasalahan terkait dimensi kualitas hasil berdasarkan pengaduan pelanggan yang diterima PT Pos Indonesia Bandung dan menurut karyawan bagian pengaduan dan solusi pelanggan, ditemukan bahwa pada tahun 2015 sebanyak 3.622 orang mengadu tentang keterlambatan atau belum diterimanya surat dan paket yang dikirim dikarenakan alat transportasi overload atau penuh atau dalam antrian kiriman akibat banyaknya pengiriman serta alat angkutnya terbatas dan salah salur, sebanyak 84 orang mengadu tentang kehilangan barang dan 84 orang mengadu tentang kiriman tidak utuh yang disebabkan kiriman dicuri seperti barang-barang yang dapat dijual yang diketahui ketika pembongkaran kantung pos karena pengecekan kiriman pos hanya dilakukan per kantung dan tidak dihitung isi di dalam kantungnya, sebanyak 21 orang mengadu tentang surat dan paket yang diterima tidak sesuai dengan yang dikirim, hal ini dikarenakan adanya kesamaan nama atau tempat sehingga karyawan salah menyerahkan, sebanyak 237 orang mengadu bahwa surat dan paket dikirim salah salur sehingga barang tidak sampai ditempat tujuan karena pelanggan salah dalam penulisan alamat dan tidak lengkap serta kesalahan karyawan dalam memasukkan kantung pos seperti tujuan surabaya di masukkan ke semarang, dan sebanyak 939 orang mengadu tentang salah update status yaitu status pengiriman dengan status penerimaan tidak sesuai seperti kiriman status terantar padahal belum, hal ini 
Tabel 1 Analisis Deskriptif Kinerja Pelayanan

\begin{tabular}{|l|c|c|c|r|r|}
\hline \multicolumn{1}{|c|}{ Variabel Kinerja Pelayanan } & $\mathbf{N}$ & Minimum & Maximum & Mean & $\begin{array}{c}\text { Std. } \\
\text { Deviation }\end{array}$ \\
\hline Interaction Quality & 115 & 2 & 5 & 3,84 & 0,568 \\
\hline Physical Environment Quality & 115 & 2 & 5 & 3,53 & 0,638 \\
\hline Outcome Quality & 115 & 2 & 5 & 3,60 & 0,631 \\
\hline Variabel Kinerja Pelayanan & $\mathbf{1 1 5}$ & $\mathbf{2}$ & $\mathbf{5}$ & $\mathbf{3 , 6 6}$ & $\mathbf{0 , 5 3 8}$ \\
\hline
\end{tabular}

Tabel 2 Analisis Deskriptif Loyalitas Pelanggan

\begin{tabular}{|l|c|c|c|r|r|}
\hline Variabel Loyalitas Pelanggan & $\mathbf{N}$ & Minimum & Maximum & Mean & $\begin{array}{c}\text { Std. } \\
\text { Deviation }\end{array}$ \\
\hline Repeat Purchase & 115 & 1 & 5 & 3,47 &, 828 \\
\hline Purchases Across Line & 115 & 1 & 5 & 3,47 &, 766 \\
\hline Refers Others & 115 & 1 & 5 & 3,48 &, 772 \\
\hline Immunity & 115 & 1 & 5 & 2,94 &, 915 \\
\hline Variabel Loyalitas Pelanggan & $\mathbf{1 1 5}$ & $\mathbf{1}$ & $\mathbf{5}$ & $\mathbf{3 , 3 4}$ & $\mathbf{, 6 6 2}$ \\
\hline
\end{tabular}

dikarenakan penerima tidak ada di rumah sehingga yang menerima orang lain sebagai perwakilan dan penerima lupa memberitahukan kiriman tersebut ke orang yang dituju. Data pengaduan tersebut meningkat dari tahun 2013. Hal ini bisa terjadi karena populasi untuk pelanggan PT Pos Indonesia banyak dan tidak diketahui jumlah populasinya, dimana sampel yang diambil sebanyak 115 orang, maka hal itu memungkinkan 115 orang responden tersebut belum semua yang termasuk dalam jumlah pengaduan pelanggan tersebut. Meskipun begitu, dapat disimpulkan bahwa kualitas hasil dari PT Pos Indonesia sudah baik/tinggi. Pada service performance yang menjadi alat ukur kualitas jasa hanya didasarkan pada performance yakni kinerja personil perusahaan maupun semua fasilitas yang digunakan, maka perlu diperhatikan proses penyampaian jasa kepada pelanggan agar kualitas jasa sesuai dengan maksud perusahaan (Cronin \& Taylor, 1992 dalam Marbun dan Suardhika, 2013:54).

Berdasarkan pembahasan tersebut, maka dapat disimpulkan bahwa kinerja pelayanan PT Pos Indonesia sudah baik/tinggi, hal ini terlihat dari nilai rata-rata (mean) yang ditunjukkan oleh ketiga dimensi yaitu kualitas interaksi (interaction quality), kualitas lingkungan fisik (physical environment quality), dan kualitas hasil (outcome quality) berada pada kategori baik/tinggi.

\section{Analisis Deskriptif Loyalitas Pelanggan}

Dilihat pada tabel 2, variabel loyalitas pelanggan memiliki rata-rata (mean) sebesar 3,34 sehingga berada pada interval 2,60 - 3,39 yang artinya loyalitas pelanggan surat dan paket pos di PT Pos Indonesia Bandung tergolong kategori biasa/sedang. Hal ini mengindikasikan bahwa loyalitas pelanggan surat dan paket di PT Pos Indonesia Bandung dinilai biasa/sedang berdasarkan keinginan pelanggan untuk menggunakan jasa secara berulang atau terus-menerus, tertarik dan menggunakan jenis jasa lain atau produk lain di PT Pos Indonesia, memberitahukan dan menyarankan kepada orang lain untuk menggunakan jasa kurir di PT Pos Indonesia, merasa puas dengan jasa kurir di PT Pos Indonesia, dan tidak tertarik dengan jasa kurir di perusahaan lain. Menurut Griffin (2005:31), loyalitas pelanggan terdiri dari empat dimensi yaitu repeat purchases, 
purchases across product and service lines, refers others, dan demonstrates immunity to the pull of the competition.

Dimensi repeat purchase tergolong kategori baik/tinggi dengan mean sebesar 3,47 . Hal ini mengindikasikan bahwa loyalitas pelanggan untuk menggunakan jasa kurir surat dan paket secara berulang di PT Pos Indonesia Bandung berada pada kategori baik/tinggi yang berarti pelanggan akan ke kantor pos apabila pelanggan akan mengirimkan surat dan paket pos, namun untuk penggunaan secara terus-menerus (indikator continue) berada pada kategori biasa/sedang. Menurut Sudaryono (2014:53) bahwa pembeli dalam membeli suatu merek didasarkan atas kebiasaan mereka selama ini. Berdasarkan pengalaman pelanggan, yakni pelanggan akan menggunakan jasa kurir surat dan paket di PT Pos Indonesia seperti untuk pengiriman jasa kurir paket ke luar pulau, proses pengirimannya cepat dan harga relatif lebih murah dibandingkan dengan pesaing, maka pelanggan akan ke kantor pos apabila akan mengirimkan paket ke luar pulau.

Dimensi purchases across line tergolong kategori baik/tinggi dengan mean sebesar 3,47. Hal ini mengindikasikan bahwa loyalitas pelanggan surat dan paket pos untuk tertarik dan menggunakan produk atau jasa lain di PT Pos Indonesia Bandung berada pada kategori baik/tinggi yang berarti pelanggan tertarik untuk menggunakan jasa atau produk lain yang ada di PT Pos Indonesia selain menggunakan surat dan paket pos. Menurut Griffin (2005:31), pelanggan yang loyal akan membeli antarlini produk atau jasa (purchases across product and service lines), yaitu konsumen tidak hanya membeli satu jenis produk atau jasa, tetapi konsumen juga membeli produk atau jasa yang lain dari perusahaan yang sama. Berdasarkan pengalaman pelanggan, yakni pelanggan akan menggunakan jasa atau produk lain yang ada di PT Pos Indonesia seperti pembayaran, pembelian materai, pengiriman uang, dan lain-lain selain jasa kurir surat dan paket di PT Pos Indonesia.

Dimensi refers others tergolong kategori baik/tinggi dengan mean sebesar 3,48. Hal ini mengindikasikan bahwa loyalitas pelanggan untuk merekomendasikan kepada orang lain mengenai jasa kurir surat dan paket di PT Pos Indonesia Bandung berada pada kategori baik/tinggi yang berarti pelanggan akan memberitahukan keunggulan jasa kurir surat dan paket di PT Pos Indonesia Bandung dan menyarankan kepada orang lain untuk menggunakan jasa kurir tersebut. Menurut Rahmayanty (2010:10), kesediaan merekomendasikan perusahaan kepada orang lain yaitu mengatakan hal-hal yang baik mengenai produk atau jasa perusahaan kepada pihak lain untuk segera menggunakan produk atau jasa tersebut. Berdasarkan pengalaman pelanggan, yakni pelanggan akan memberitahukan keunggulan dari jasa surat dan paket pos kepada orang lain dan menyarankan kepada orang lain untuk menggunakan jasa tersebut karena pelanggan merasa puas dengan jasa di PT Pos Indonesia. Hal tersebut sesuai dengan teori menurut Sudaryono (2014:53) bahwa manfaat yang dapat diberikan dari loyalitas pelanggan adalah dengan menarik minat pelanggan baru yaitu jika pelanggan merasa puas, maka akan merekomendasikan merek tersebut kepada orang yang dekat dengannya sehingga akan menarik pelanggan baru.

Dimensi immunity tergolong kategori biasa/sedang dengan mean sebesar 2,94. Hal ini mengindikasikan bahwa loyalitas pelanggan untuk tidak tertarik dengan jasa kurir surat dan paket dari perusahaan lain dan setia kepada PT Pos Indonesia berada pada kategori biasa/sedang, namun pelanggan merasa puas dengan PT Pos Indonesia berada pada kategori baik/tinggi yang berarti pelanggan merasa puas dengan jasa surat dan paket di PT Pos Indonesia, namun pelanggan masih tertarik dengan jenis jasa kurir surat dan paket dari perusahaan lain dan belum terlalu setia 
kepada PT Pos Indonesia Bandung. Berdasarkan pengalaman pelanggan, yakni pelanggan masih menggunakan jasa kurir surat dan paket dari perusahaan lain seperti pelanggan masih menggunakan jasa kurir surat dan paket dari JNE karena pada PT Pos Indonesia harga kirim surat dan paket pos yang berada di pulau yang sama lebih mahal dibandingkan pesaing misalnya pengiriman dari Banjaran ke Majalaya dengan berat kiriman $1 \mathrm{~kg}$ maka harga pada Pos sebesar Rp. 15.000 dengan estimasi waktu 2-4 hari, sedangkan pada JNE sebesar Rp. 8.000 dengan estimasi waktu 2-3 hari. Menurut Rahmayanty (2010:10), jika dilihat dari perilaku pelanggan dan kepuasan yang diterima maka wujud dari kesetiaan pelanggan adalah dengan menolak untuk berpaling pada pesaing perusahaan yaitu kurang memperhatikan merek dan iklan dari produk atau jasa pesaing. Konsistensi penggunaan produk atau jasa pelayanan perusahaan walaupun terdapat perubahan harga, kemasan, ataupun pelayanan dari perusahaan. Maka, hal itu belum sesuai dengan teori tersebut.

Berdasarkan pembahasan tersebut, maka dapat disimpulkan bahwa loyalitas pelanggan terhadap PT Pos Indonesia biasa/sedang, maka loyalitas pelanggan di PT Pos Indonesia masih lemah atau inertia loyalty. Menurut Griffin, (2005:22), loyalitas yang lemah atau inertia loyalty merupakan jenis loyalitas yang dihasilkan dari keterikatan yang rendah digabung dengan pembelian berulang yang tinggi.

Dimensi repeat purchase tergolong kategori baik/tinggi dengan mean sebesar 3,47 . Hal ini mengindikasikan bahwa loyalitas pelanggan untuk menggunakan jasa kurir surat dan paket secara berulang di PT Pos Indonesia Bandung berada pada kategori baik/tinggi yang berarti pelanggan akan ke kantor pos apabila pelanggan akan mengirimkan surat dan paket pos, namun untuk penggunaan secara terus-menerus (indikator continue) berada pada kategori biasa/sedang. Menurut Sudaryono (2014:53) bahwa pembeli dalam membeli suatu merek didasarkan atas kebiasaan mereka selama ini. Berdasarkan pengalaman pelanggan, yakni pelanggan akan menggunakan jasa kurir surat dan paket di PT Pos Indonesia seperti untuk pengiriman jasa kurir paket ke luar pulau, proses pengirimannya cepat dan harga relatif lebih murah dibandingkan dengan pesaing, maka pelanggan akan ke kantor pos apabila akan mengirimkan paket ke luar pulau.

Dimensi purchases across line tergolong kategori baik/tinggi dengan mean sebesar 3,47. Hal ini mengindikasikan bahwa loyalitas pelanggan surat dan paket pos untuk tertarik dan menggunakan produk atau jasa lain di PT Pos Indonesia Bandung berada pada kategori baik/tinggi yang berarti pelanggan tertarik untuk menggunakan jasa atau produk lain yang ada di PT Pos Indonesia selain menggunakan surat dan paket pos. Menurut Griffin (2005:31), pelanggan yang loyal akan membeli antarlini produk atau jasa (purchases across product and service lines), yaitu konsumen tidak hanya membeli satu jenis produk atau jasa, tetapi konsumen juga membeli produk atau jasa yang lain dari perusahaan yang sama. Berdasarkan pengalaman pelanggan, yakni pelanggan akan menggunakan jasa atau produk lain yang ada di PT Pos Indonesia seperti pembayaran, pembelian materai, pengiriman uang, dan lain-lain selain jasa kurir surat dan paket di PT Pos Indonesia.

Dimensi refers others tergolong kategori baik/tinggi dengan mean sebesar 3,48. Hal ini mengindikasikan bahwa loyalitas pelanggan untuk merekomendasikan kepada orang lain mengenai jasa kurir surat dan paket di PT Pos Indonesia Bandung berada pada kategori baik/tinggi yang berarti pelanggan akan memberitahukan keunggulan jasa kurir surat dan paket di PT Pos Indonesia Bandung dan menyarankan kepada orang lain untuk menggunakan jasa kurir tersebut. Menurut Rahmayanty (2010:10), kesediaan merekomendasikan perusahaan kepada orang lain yaitu mengatakan hal-hal yang 
baik mengenai produk atau jasa perusahaan kepada pihak lain untuk segera menggunakan produk atau jasa tersebut. Berdasarkan pengalaman pelanggan, yakni pelanggan akan memberitahukan keunggulan dari jasa surat dan paket pos kepada orang lain dan menyarankan kepada orang lain untuk menggunakan jasa tersebut karena pelanggan merasa puas dengan jasa di PT Pos Indonesia. Hal tersebut sesuai dengan teori menurut Sudaryono (2014:53) bahwa manfaat yang dapat diberikan dari loyalitas pelanggan adalah dengan menarik minat pelanggan baru yaitu jika pelanggan merasa puas, maka akan merekomendasikan merek tersebut kepada orang yang dekat dengannya sehingga akan menarik pelanggan baru.

Dimensi immunity tergolong kategori biasa/sedang dengan mean sebesar 2,94. Hal ini mengindikasikan bahwa loyalitas pelanggan untuk tidak tertarik dengan jasa kurir surat dan paket dari perusahaan lain dan setia kepada PT Pos Indonesia berada pada kategori biasa/sedang, namun pelanggan merasa puas dengan PT Pos Indonesia berada pada kategori baik/tinggi yang berarti pelanggan merasa puas dengan jasa surat dan paket di PT Pos Indonesia, namun pelanggan masih tertarik dengan jenis jasa kurir surat dan paket dari perusahaan lain dan belum terlalu setia kepada PT Pos Indonesia Bandung. Berdasarkan pengalaman pelanggan, yakni pelanggan masih menggunakan jasa kurir surat dan paket dari perusahaan lain seperti pelanggan masih menggunakan jasa kurir surat dan paket dari JNE karena pada PT Pos Indonesia harga kirim surat dan paket pos yang berada di pulau yang sama lebih mahal dibandingkan pesaing misalnya pengiriman dari Banjaran ke Majalaya dengan berat kiriman $1 \mathrm{~kg}$ maka harga pada Pos sebesar Rp. 15.000 dengan estimasi waktu 2-4 hari, sedangkan pada JNE sebesar Rp. 8.000 dengan estimasi waktu 2-3 hari. Menurut Rahmayanty (2010:10), jika dilihat dari perilaku pelanggan dan kepuasan yang diterima maka wujud dari kesetiaan pelanggan adalah dengan menolak untuk berpaling pada pesaing perusahaan yaitu kurang memperhatikan merek dan iklan dari produk atau jasa pesaing. Konsistensi penggunaan produk atau jasa pelayanan perusahaan walaupun terdapat perubahan harga, kemasan, ataupun pelayanan dari perusahaan. Maka, hal itu belum sesuai dengan teori tersebut.

Berdasarkan pembahasan tersebut, maka dapat disimpulkan bahwa loyalitas pelanggan terhadap PT Pos Indonesia biasa/sedang, maka loyalitas pelanggan di PT Pos Indonesia masih lemah atau inertia loyalty. Menurut Griffin, (2005:22), loyalitas yang lemah atau inertia loyalty merupakan jenis loyalitas yang dihasilkan dari keterikatan yang rendah digabung dengan pembelian berulang yang tinggi.

\section{Analisis Korelasi}

Berdasarkan tabel 3, dapat dilihat pada pearson correlation bahwa nilai korelasi antara variabel kinerja pelayanan dan loyalitas pelanggan sebesar 0,740 dengan arah hubungan positif sehingga berada di rentang 0,60 - 0,799 yang artinya terdapat hubungan positif yang kuat. Selain itu, diperoleh nilai signifikansi sebesar 0,000

Tabel 3 Analisis Korelasi

\begin{tabular}{|l|l|l|l|}
\hline \multicolumn{2}{|c|}{ Korelasi } & \multicolumn{1}{c|}{$\begin{array}{c}\text { Kinerja } \\
\text { Pelayanan }\end{array}$} & \multicolumn{1}{c|}{$\begin{array}{c}\text { Loyalitas } \\
\text { Pelanggan }\end{array}$} \\
\hline \multirow{3}{*}{ Kinerja Pelayanan } & Pearson Correlation & 1 & $0,740^{* *}$ \\
\cline { 2 - 4 } & Sig. (2-tailed) & & 0,000 \\
\cline { 2 - 4 } & $\mathrm{N}$ & 115 & 115 \\
\hline \multirow{3}{*}{ Loyalitas Pelanggan } & Pearson Correlation & $0,740^{* *}$ & 1 \\
\cline { 2 - 4 } & Sig. (2-tailed) & 0,000 & 115 \\
\cline { 2 - 4 } & $\mathrm{N}$ & 115 & \\
\hline
\end{tabular}


Tabel 4 Analisis Regresi Linier Sederhana

\begin{tabular}{|c|c|c|c|c|c|c|}
\hline \multirow{2}{*}{ Model } & \multicolumn{2}{|c|}{$\begin{array}{c}\text { Unstandardized } \\
\text { Coefficients }\end{array}$} & $\begin{array}{c}\text { Standardized } \\
\text { Coefficients }\end{array}$ & \multirow{2}{*}{ t } & \multirow{2}{*}{ Sig. } \\
\cline { 3 - 5 } \multicolumn{2}{|c|}{} & B & Std. Error & Beta & & \\
\hline \multirow{2}{*}{1} & (Constant) & $-2,502$ & 3,037 & & $-0,824$ & 0,412 \\
\cline { 2 - 7 } & $\begin{array}{c}\text { Kinerja } \\
\text { Pelayanan }\end{array}$ & 0,435 & 0,037 & 0,740 & 11,688 & 0,000 \\
\hline
\end{tabular}

yang artinya korelasi tersebut signifikan karena nilai sig $<0,05$. Hal ini dapat dinyatakan bahwa semakin tinggi kinerja pelayanan PT Pos Indonesia maka semakin tinggi pula loyalitas pelanggan surat dan paket pos.

\section{Analisis Regresi Linier Sederhana}

Berdasarkan tabel 4, jika dilihat pada kolom unstandardized coefficients, nilai konstanta (a) sebesar -2,502 dengan koefisien regresi (b) sebesar 0,435. Maka diperoleh persamaan regresi linear sederhana sebagai berikut:

$$
\begin{aligned}
& Y=a+b X \\
& Y=-2,502+0,435 X
\end{aligned}
$$

Nilai a dan $b$ di atas dapat diinterpretasikan sebagai beriku:

1. Konstanta (a) sebesar -2,502 dapat diartikan jika kinerja pelayanan nilainya sama dengan nol $(X=0)$ atau tidak ada kinerja pelayanan, maka loyalitas pelanggan nilainya negatif yaitu sebesar $-2,502$.

2. Koefisien regresi (b) variabel kinerja pelayanan sebesar 0,435 yang artinya jika kinerja pelayanan mengalami kenaikan satu satuan maka loyalitas pelanggan akan mengalami kenaikan sebesar 0,435 satuan. Koefisien bernilai positif artinya terjadi hubungan positif antara kinerja pelayanan dengan loyalitas pelanggan yaitu apabila kinerja pelayanan meningkat, maka loyalitas pelanggan juga meningkat.

\section{KESIMPULAN DAN SARAN Kesimpulan}

Berdasarkan hasil pengumpulan data, pengolahan data, dan analisis yang telah dilakukan serta menjawab tujuan pada identifikasi masalah dari penelitian ini, maka dapat disimpulkan bahwa:

1. Kinerja pelayanan di PT Pos Indonesia Bandung berada pada kategori baik/tinggi. Dimensi interaction quality atau kualitas interaksi merupakan dimensi yang memiliki nilai rata-rata atau mean tertinggi dan masuk kategori baik/tinggi, sedangkan dimensi physical environment quality atau kualitas lingkungan fisik merupakan dimensi yang memiliki nilai rata-rata atau mean terendah, namun berada pada kategori baik/tinggi.

2. Loyalitas pelanggan surat dan paket di PT Pos Indonesia Bandung tergolong kategori biasa/sedang. Dimensi refers others merupakan dimensi yang memiliki nilai rata-rata atau mean tertinggi dan masuk kategori baik/tinggi, sedangkan dimensi immunity merupakan dimensi yang memiliki nilai rata-rata atau mean terendah, namun berada pada kategori biasa/sedang. Hal itu menyatakan bahwa loyalitas pelanggan di PT Pos Indonesia masih lemah atau inertia loyalty yaitu pelanggan merasa puas kepada PT Pos Indonesia dengan kesetiaan yang biasa/sedang, namun pelanggan masih tertarik dengan jenis jasa surat dan paket dari perusahaan lain.

3. Kinerja pelayanan berpengaruh secara signifikan terhadap loyalitas pelanggan surat dan paket di PT Pos Indonesia Bandung yaitu sebesar 54,7\%, sementara sisanya sebesar $45,3 \%$ dipengaruhi oleh faktor-faktor lain reputasi merek, citra perusahaan, kepuasan pelanggan dan harga yang tidak dijelaskan pada penelitian ini. 
Saran

Saran yang dapat berhubungan dengan penelitian yang dilakukan adalah sebagai berikut:

1. Sebaiknya PT Pos Indonesia menambahkan jumlah angkutan agar dapat meminimalisir keterlambatan. Karyawan mengecek kembali nama dan alamat tujuan dari pelanggan agar tidak terjadi kesalahan pada nama dan alamat tujuan serta agar tidak terjadi salah serah. Karyawan mengecek kembali kiriman sebelum mengantarkan kiriman agar tidak ada kiriman yang salah masuk. Karyawan juga sebaiknya melakukan pengecekan pada nomor seal yang tertera pada kantung pos agar nomor seal yang tertera pada kantung pos selalu sesuai pada saat sampai ditempat tujuan dan melakukan pengawasan terhadap pengiriman kantung pos seperti mengecek nomor seal pada kantung pos dan mengecek kondisi kantung pos apabila kantung pos akan berpindah, lakukan hal tersebut sampai kantung pos tiba di tempat tujuan agar tidak terjadi kehilangan atau tidak utuhnya kiriman. Kejelasan saat mengupdate status penerimaan barang seperti jelaskan secara rinci apabila barang telah sampai dengan keterangan dititipkan ke orang lain atas nama penerima kiriman.

2. Sebaiknya PT Pos Indonesia memberikan penawaran-penawaran yang menarik seperti undian yaitu pengumpulan bukti transaksi sesuai yang ditentukan perusahaan yang nanti akan diundi dan akan mendapatkan hadiah, serta membuat kartu keanggotaan atau member card dimana pada saat melakukan pembayaran pengiriman mendapatkan diskon member. Kemudian harga pengiriman untuk paket dalam pulau yang sama sebaiknya dipertimbangkan penetapan tarifnya sebab harga dari pesaing lebih murah dari PT Pos Indonesia untuk pengiriman dalam pulau yang sama. Hal ini dilakukan agar pelanggan hanya tertarik pada PT Pos Indonesia dan pelanggan akan menggunakan jasa tersebut secara continue.

3. Penelitian ini memiliki keterbatasan waktu, sehingga untuk pengukuran kinerja pelayanan dan loyalitas pelanggan surat dan paket pos hanya dilakukan kepada pelanggan yang ditemui pada saat penyebaran kuesioner dan yang menerima kuesioner secara online sebanyak 115 responden. Maka dari itu, untuk peneliti selanjutnya, sebaiknya menambahkan jumlah sampel dalam meneliti variabel tersebut serta penyebaran kuesioner dilakukan dalam waktu yang lama agar pelanggan yang ditemui bervariasi.

4. Penelitian ini terbatas pada satu objek penelitian saja, yaitu PT Pos Indonesia Bandung. Untuk penelitian selanjutnya, dapat dilakukan penelitian di PT Pos Indonesia di daerah Bandung secara keseluruhan atau tempat penelitian lain.

\section{DAFTAR PUSTAKA}

Andri, G. (2011). Pengaruh Kinerja Pelayanan RS Islam Ibnu Sina dan Kepuasan Pasien sebagai Variabel Moderator terhadap Loyalitas Pasien pada RS Islam Ibnu Sina di Sumatera Barat. Jurnal Manajemen dan Kewirausahaan. Vol 2: hal 59, 61, 62

Bohl, P. (2012). The Effect of Store Atmosphere on Shopping Behaviour. International Journal of Carvinus Marketing Studies. Hal 6

Griffin, J. (2005). Customer Loyalty: Menumbuhkan dan Mempertahankan Kesetiaan Pelanggan. Diterjemahkan oleh: Dwi Kartini Yahya. Jakarta: Erlangga

Purwanto, A. B. (2015). Pengaruh Service Performance dan Relationship Marketing terhadap Loyalitas Konsumen. Jurnal Ekonomi. Vol 10: hal 89,90 
Laksmi, F. G., \& Budiantoro. (2015). Manajemen Perkantoran Modern. Jakarta: PT Rajagrafindo Persada

Lovelock, C., \& Wirtz, J. (2011). Service Marketing: People, Technology, Strategy 7th Edition. New Jersey: Prentice Hall

Lucas, R. W. (2015). Customer Service: Skills for Success, Sixth Edition. New York: MC Graw-Hill Education

Marbun, S., \& Suardhika, I. N. (2013). Pengaruh Service Performance terhadap Nilai Institusi dan Kepuasan Mahasiswa (Studi pada Stipar Triatma Jaya). Jurnal Manajemen dan Akuntansi. Vol 19: hal 54, 60

Rahayu, S. (2015). Faktor-faktor yang mempengaruhi Loyalitas Pelanggan Minuman Jamu Gendong di Surakarta. Jurnal Bhirawa. Vol 2: hal 55

Rahmayanty, N. (2010). Manajemen Pelayanan Prima. Yogyakarta: Graha Ilmu

Sangadji, M., \& Sopiah. (2013). Perilaku Konsumen: Pendekatan Praktis disertai Himpunan Jurnal Penelitian. Yogyakarta: Andi
Sudaryono. (2014). Perilaku Konsumen: dalam Persepektif Pemasaran. Jakarta: Lentera Ilmu Cendekia

PT Pos Indonesia. (2015). Annual Report. Change Management Office

PT Pos Indonesia. (2015). Complain Handling Pos. Bagian Pengaduan dan Solusi Pelanggan

Purwanto, A. B. (2015). Pengaruh Service Performance dan Relationship Marketing terhadap Loyalitas Konsumen. Jurnal Ekonomi. Vol 10: hal 89,90

Tjiptono, F. (2012). Service Management: Mewujudkan Layanan Prima. Yogyakarta: Andi

Sudaryono. (2014). Perilaku Konsumen: dalam Persepektif Pemasaran. Jakarta: Lentera Ilmu Cendekia

Sugiyono. (2014). Metode Penelitian Bisnis. Bandung: Alfabeta

Sultan, P., \& Wong, H. (2010). Performance-based Service Quality Model: an Empirical Study on Japanese Universities. International Journal of Quality Assurance in Education. Vol 18: hal 128

Wijaya, T. (2011). Manajemen Kualitas Jasa. Jakarta: PT Indeks 